\title{
Introduction: the Mexican cartels-organized crime vs. criminal insurgency
}

\author{
Robert J. Bunker
}

Published online: 28 March 2013

(C) Springer Science+Business Media New York 2013

This special issue of Trends in Organized Crime on the 'Mexican Cartels' brings together contributors from academic, policy, military, security consulting, and investigative reporting backgrounds with some currently, or in the past, engaged in overlapping professional roles. The topic is of significance because these groups have developed from drug trafficking organizations to transnational criminal entities operating not only in Mexico but increasingly in Central America, throughout the United States, and in other regions of the Western hemisphere, West Africa, and Asia. It is important to understand this process and to remember that Mexico did not always have cartels. Since their initial appearance in the late 1980s, they have greatly evolved with the preferred narcotics route into the U.S. shifting from Southern Florida to over the U.S. border via Mexico and with the subsequent dismantling of the major cartels found in Colombia in the 1990s. Cartel evolution has been influenced by numerous factors ranging from intentional and unintentional governmental policies and second order effects, through changes in illicit market preferences and flows, to cartel mergers, infighting, and innovations. Typically, forgotten events that have directly impacted the rise of cartels include the torture killing of DEA agent Enrique "Kiki" Camarena in Mexico in 1985, U.S. counter-narcotics efforts spearheaded by the DEA to track down those responsible, and the initial establishment of the 'plaza system' by Miguel Ángel Felix Gallardo ('El Padrino") in the 1987-1989 era as a defensive countermove against those efforts.

The process of political transition in Mexico from an autocratic - seventy-year one party dominated system under the Partido Revolucionario Institucional (PRI) - to a democratic multiparty system beginning in 2000 further greatly influenced cartel evolution. Under the PRI, the major cartels in Mexico, each with their assigned territories (plazas) remained subordinate to a state whose officials and elite families quietly profited from the illicit narcotics trade. This relationship with the state drastically changed with the election of two Partido Acción Nacional (PAN) administrations under Vincente Fox (2000-2006) and then Felipe Calderón (2006-1012).

The views expressed in this essay are those of the author and do not necessarily reflect the official policy or position of the Department of the Army, the Department of Defense, or the U.S. Government.

R. J. Bunker $(\bowtie)$

Strategic Studies Institute, U.S. Army War College, Carlisle, PA 17013, USA

e-mail: robert.j.bunker2@us.army.mil 
The old governmental institutional relationships were altered with the balance of power slowly shifting over to the cartels. The relationship between the state and these growing criminal organizations - and amongst these due to conflict over the lucrative plazas - increasingly becoming strained as the violence levels escalated and governmental authority was lost in what became hundreds of 'areas of impunity' (e.g. de facto cartel zones of control) within Mexico (Fig. 1).

In less than three decades, the nascent Mexican cartels have morphed from simple drug trafficking families situated in key transshipment cities (plazas) into drug cartels in larger regional areas and then into polygot criminal organizations. The latter have metastasized throughout Mexico, Central America, and beyond with annual revenues in the tens-of-billions of U.S. dollars and personnel (including foot-soldiers and armed gang contractors) numbering in the hundreds-of-thousands. The significance disciplines that study organized criminal groups place on the rise and evolution of these cartels, and their gang associates, is now of heightened interest not only to academics but also to policymakers and even the person on the street impacted by the various forms of criminal activities that those criminal groups promote.

\section{Organized crime vs. criminal insurgency}

One of the dominant academic debates taking place with regard to the Mexican cartels is the threat that they may pose to sovereign states. The outlines of this debate can be seen

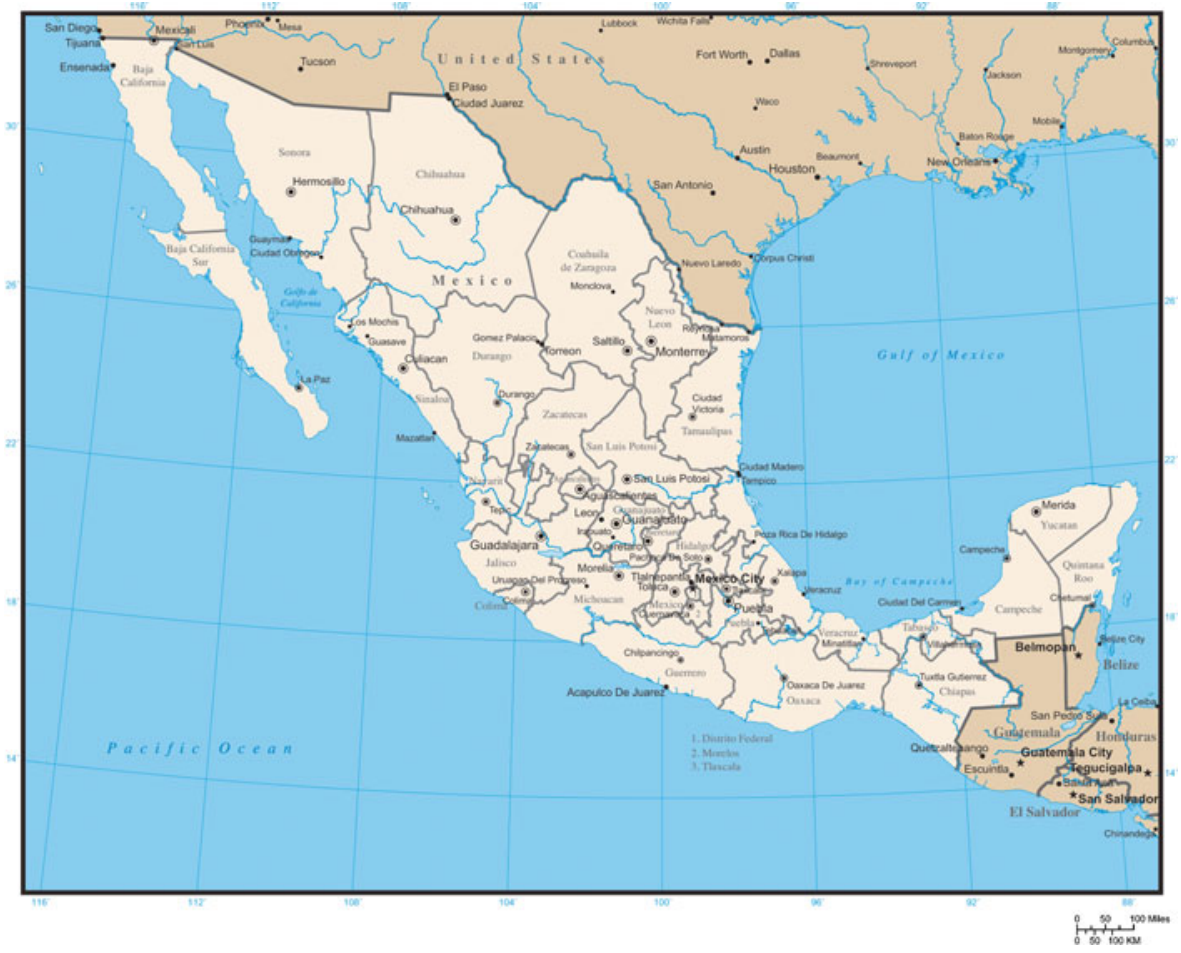

Fig. 1 Map of Mexico 
Table 1 Organized crime vs. criminal insurgency

\begin{tabular}{|c|c|c|}
\hline & Organized crime & Criminal insurgency ${ }^{\mathrm{a}}$ \\
\hline Security paradigm & $\begin{array}{l}\text { Modern (State based challengers/ } \\
\text { Realism) }\end{array}$ & $\begin{array}{l}\text { Post-modern (Non-state based } \\
\text { challengers/Epochal) }\end{array}$ \\
\hline Insurgency paradigm & $\begin{array}{l}\text { None (Insurgency is only politically } \\
\text { based; Maoist) }\end{array}$ & $\begin{array}{l}\text { Criminal based (Tilly, van Creveld, } \\
\text { Felbab-Brown) }\end{array}$ \\
\hline Cartels as & $\begin{array}{l}\text { Organized crime (OC) Transnational } \\
\text { organized crime (TOC) }\end{array}$ & $\begin{array}{l}\text { New war-making entities (State } \\
\text { challengers/co-opters) }\end{array}$ \\
\hline Cartel members as & Violent entrepreneurs (Criminals) & Criminal-soldiers (Criminal-insurgents) \\
\hline Focus of cartel effort & Hypercompetitive (illicit) market & $\begin{array}{l}+ \text { Create criminal enclaves (Areas of } \\
\text { impunity) }\end{array}$ \\
\hline Cartel politicization & None & De facto (Free from state influence) \\
\hline Threat environment & $\begin{array}{l}\text { High intensity crime (HIC) (No threat } \\
\text { to state integrity or oblique one) }\end{array}$ & $\begin{array}{l}\text { Low intensity conflict (LIC) (Direct } \\
\text { threat to state integrity) }\end{array}$ \\
\hline $\begin{array}{l}\text { Dominant internecine } \\
\text { (cartel vs. cartel) } \\
\text { violence signifies }\end{array}$ & $\begin{array}{l}\text { State institutions and agents not being } \\
\text { directly targeted-secondary } \\
\text { consideration/No insurgency in effect }\end{array}$ & $\begin{array}{l}\text { Agent targeting though corruption the } \\
\text { preferred insurgent technique/State } \\
\text { institutions and agents at times } \\
\text { irrelevant to the conflict }\end{array}$ \\
\hline Response paradigm & $\begin{array}{l}\text { Law enforcement (High intensity } \\
\text { policing) }\end{array}$ & + Military (National security threat) \\
\hline Response goal & $\begin{array}{l}\text { Bring criminal offenders to justice/ } \\
\text { Prevent increase in violent crime/Low } \\
\text { intensity crime is desired end state }\end{array}$ & $\begin{array}{l}\text { + Target and neutralize king-pins/ } \\
\text { Dismantle dominant cartels } \\
+ \text { Reestablish state legitimacy and } \\
\text { solvency in contested and lost areas }\end{array}$ \\
\hline
\end{tabular}

Sources: (Kan and Williams 2010; Kan 2011; Sullivan and Elkus 2010; Sullivan and Bunker 2011). Updated information provided by Paul Rexton Kan, John P. Sullivan, and Robert J. Bunker

A table portraying the differences between low-intensity conflict (LIC) and high-intensity crime (HIC) will appear in Paul Rexton Kan, Cartels at War: Understanding Mexico's Drug Fueled Violence and the Challenge to US National Security, Potomac Books: Dulles, 2012. It provides a different schema of organized crime (law enforcement) and national security (military) perspectives on the Mexican cartels

${ }^{a}$ Criminal insurgency is viewed as a sub-variant of commercial insurgency. See Metz (1993) The Future of Insurgency, Strategic Studies Institute, U.S. Army War College: Carlisle

in Table 1: Organized crime vs. criminal insurgency. ${ }^{1}$ The debate is taking place not only in online professional publications - such as in Small Wars Journal and Insight Crimeand in more generalized blogs — such as Borderland Beat - but in the halls of the U.S. Congress, within military commands, and to think tanks and peer reviewed academic journals such as Organized Crime and Terrorism and Political Violence. Even Stanford University now has an ongoing project on the 'Dynamics of Extortion in Mexico's Criminal Insurgency’ (FSI Stanford, http://fsi.stanford.edu/research/networks_of_fear_ the dynamics_of_extortion_in_mexicos_criminal_insurgency/).

For the readers of Trends in Organized Crime this debate is of great significance because modernist (dominant) and post-modernist (emerging) paradigms are increasingly at odds with one another. The basic assumptions behind these competing

\footnotetext{
${ }^{1}$ This debate resides within the broader perspectives of the various security studies disciplines vis-à-vis the Mexican cartels and gangs. See (Bunker 2011).
} 
paradigms provide dominant decision tree perspectives pertaining to the raison d'être or imperatives driving the Mexican cartels and their activities. The outcome of this debate may very well help to shape the study of organized crime (OC) and transnational organized crime (TOC) viewpoints concerning the cartels for years to come.

The modernist view of organized crime exists within a security paradigm that accedes to the realism of Morgenthau (1948), Waltz (1979) and Mearsheimer (2001). One of the main tenets promoted by realism is that only states are able to effectively challenge other states - non-state entities are incapable of rising to the level of national security threats. Further, organized crime is said to be devoid of any form of political basis and therefore is incapable of engaging in a politically based (Maoist) insurgency. Within the modernist viewpoint, cartel members are viewed as violent entrepreneurs whose focus of effort is on a hypercompetitive (illicit) market and opposing cartel members. The state is not a target of cartel efforts and the ensuing high intensity crime (HIC) environment being generated by the internecine (cartel vs. cartel) battles is no threat, or at best an oblique threat, to state integrity. The appropriate response to the Mexican cartels is said to be law enforcement, which is utilized to create a more manageable level of criminal violence by bringing offenders to justice. Major proponents of the Mexican cartels as organized crime school of thought include Phil Williams, Paul Rexton Kan, and those scholars trained in traditional criminological (sociological) studies.

The post-modernist view of criminal insurgency exists within a security paradigm that accedes to epochal change (Bunker 1997; Moore 2003). A main tenet of epochal change is not only the promotion that non-state entities (e.g. Al Qaeda) can effectively challenge states but that such non-state challengers are actively engaged in the early stages of 'warmaking and statemaking' as identified by Charles Tilly (1985), van Creveld (1991) and Vanda Felbab-Brown (2010). The more evolved Mexican cartels - specifically Los Zetas and the Knights Templars (the La Familia successor) are seen as new war-making entities that utilize 'criminal-soldiers' and have become a direct threat to the integrity of the Mexican state in their areas of operation. While the initial basis of criminal insurgency is illicit economic in origin, the cartels themselvesvia the creation of hundreds of 'areas of impunity' (which are free from state influence) are viewed as de facto politicized. Since criminal insurgencies exist in a low intensity conflict (LIC) environment, the appropriate response includes military and other national security elements. These elements are needed so that king-pins can be targeted and eliminated, the major cartels can be broken up, and state legitimacy and solvency can be reestablished in contested and lost areas. Major proponents of the Mexican cartels as criminal insurgents school of thought include John Sullivan, Robert Bunker, and those scholars who accede to non-traditional criminological and non-state threat national security perspectives.

\section{The contributions to this special issue}

This special issue on the 'Mexican Cartels' is composed of five articles and six book reviews. While these articles and reviews may be contemplated within the broader context of the organized crime vs. criminal insurgency debate, they represent standalone scholarship which, while possibly influenced by either modernist or postmodernist thinking, does not actively promote either paradigm (except for the Ioan 
Grillo and Paul Kan books being reviewed which acede to opposing criminal insurgency and organized crime perspectives, respectively). Still, an underlying tension between what are becoming emerging schools of thought can at times be detected as an undercurrent of this special issue.

The first article is written by Viridiana Rios, a $\mathrm{PhD}$ in Government from Harvard University and a doctoral fellow in Inequality and Criminal Justice at the Harvard Kennedy School. She is a leading expert in the study of recent spikes in drug-related homicides in Mexico. Her article is derived from her research on violence, corruption dynamics, and the industrial organization of crime and analyzes why drug-related homicides have recently increased in Mexico, providing an explanation of the phenomenon at the micro level. The article is based on the authoritative data set from the National Security Council (CSN) of Mexico pertaining to homicides linked to the activities of organized criminals, as well on her extensive recollection of banners written by trafficking organizations to communicate between themselves (i.e. narcomessages, a form of expression commonly used by Mexican gangs). She complements the analysis of this data set by providing a case study approach that utilizes a narrative of the patterns of violence witnessed in the Mexican states of Michoacán, Guanajuato, and Guerrero. Her premise, which is adeptly supported by the empirical evidence and analysis provided, is that drug-related violence since December 2006 in Mexico can be understood as the result of two factors: (a) homicides caused by traffickers battling to take control of a competitive market, and (b) casualties and arrests generated by law enforcement operations against traffickers. The work breaks new theoretical ground by identifying a "self-reinforcing violent equilibrium" component in the Mexican drug wars in which both aforementioned factors interact, causing Mexico to be locked into a high homicide equilibrium. In this situation, traffickers battling for turf raise the incentives of the government to enforce the law, which promotes further confrontations with traffickers when, as a result of the detention of drug lords, the remnants of the criminal organization fight each other in successive battles.

Nathan Jones, who completed his PhD in Political Science from University of California, Irvine, provides the second article which is entitled 'The unintended consequences of king-pin strategies: kidnap rates in the Arellano-Félix organization.' The article draws upon Dr. Jones' dissertation focusing on the organizational structures of the Arellano Felix Organization (AFO; Tijuana Cartel) with fieldwork conducted in Mexico City and Tijuana. His research draws upon data sets from the Baja California Secretary of Security Website and from the Instituto Ciudano de Estudios Sobre la Inseguridad (ICESI), and archival and interview-based research, including that of active US law enforcement investigators, on the history of the AFO. The article analyses the unintended consequences of 'decapitation' or 'king-pin' strategies by assessing the impact of the arrest or deaths of Arellano Felix Organization leaders in terms of kidnap and homicide levels from the late 1990's to 2011. Various findings result from the original research presented including the fact that the arrest of important AFO 'lieutenants' increased kidnapping rates. This type of analysis, performed at the operational as opposed to either the tactical or strategic level - is generally overlooked yet is of great interest to policymakers because it provides insights into cartel fragmentation processes. Other important findings were also evident including a better understanding of cartel leadership succession dynamics based on successor strategies in place. 
The third article, written by Professor Marcos Pablo Moloeznik of the Universidad de Guadalajara, in Guadalajara, Mexico, who has authored two books and dozens of book chapters is entitled 'Organized crime, the militarization of public security, and the debate on the "new" police model in Mexico.' The work discusses and provides context concerning the violence taking place in Mexico originating with both non-state criminal actors and the government of that sovereign state. Professor Moloeznik then goes on to provide a critical analysis of President Calderón's national security strategy derived from what is viewed as both the militarization of public security and an-ill conceived "new" police model. Tables in the work explaining the differences between the policing and military professions with their respective "citizen-centric" and "state-centric" perspectives and competing civilian and military police models highlight some of the concerns. Philisophical questions are futher raised pertaining to who in the Mexican government - the Department of the Interior or the Department of National Defense - should be responsible for the country's national security policy with the author siding with the rights of the Mexican public over those of the state.

Professor Stephen Morris, of Middle Tennessee State University, and author of such works as Corruption \& Politics in Contemporary Mexico (University of Alabama Press, 1991) and Political Corruption in Mexico: The Impact of Democratization (Lynne Rienner, 2009) wrote the fourth article. This fascinating and important conceptual work is entitled 'Drug Trafficking, Corruption, and Violence in Mexico: Mapping the Linkages.' Professor Morris explores the "theoretical puzzle" in Mexico represented by the links between corruption, violence, and the government's war on the cartels and drug gangs. Relationships and inverse connections between these variables are explored in the work and examples from contemporary Mexico are provided. The theses approach undertaken in the work is unique and identifies the positions of various writers on the issue of drug-related corruption and violence plaguing Mexico. Of value is the table identifying drug-related violence based on the motivation of the actor. While an exploratory work not meant to answer theoretical questions but to identify new ones, some tentative analysis is provided concerning the deteriorating position of the Mexican state in its battle against both the cartels and itself, stemming from institutions riddled with corruption.

The fifth article is by Professors Jerjes Aguirre and Hugo Amador Herrera from the Universidad Michoacana in Morelia, Mexico. These scholars have been engaged in an ongoing collaboration concerning criminal groups in Michoacán and have recently co-published 'Societal Attitudes and Organized Crime in Mexico: The Case of Michoacan, Mexico' in the International Journal of Humanities and Social Science (Aug 2012). Their article in the special issue discusses and analyzes the dynamics between institutional weakness and organized crime in Michoacán. Specifically, they apply the 'social control' of crime model utilized by criminologist Gary LaFree in his 1998 work Losing Legitimacy to the contemporary situation in Michoacán vis-à-vis the activities of the criminal organization La Familia Michoacána and its splinter group Los Caballeros Templarios. They argue in their article that drug trafficking is not the primary activity of La Familia but it is instead the 'commercial, judicial, and social functions that should be regulated by the state'. As a result, these criminal organizations fulfill a political and social function for local populations and represent much more than mere criminal entities. Discussions of the incomplete democratic transition in Mexico at the state and local levels, local corruption and lack of police 
professionalism, and issues of institutional illegitimacy are provided that suggest wide vacuums of power and authority have been filled by criminal organizations not only in Michoacán but in other regions of Mexico.

The first of the six book reviews is written by Diana Washington Valdez, a respected journalist and author of The Killing Fields: Harvest of Women (Peace at the Border, 2006). It concerns Ioan Grillo's work El Narco: Inside Mexico's Criminal Insurgency (Bloomsbury Press, 2011). El Narco provides a journalistic account of Felipe Calderón's December 2006 governmental offensive against the cartels. Valdez describes the work as a "fair and comprehensive description of the tragic events that engulfed' Mexico. Further, she sees it a good overview of "narco culture" and other elements related to the conflict including the underlying tensions between Mexico and the U.S. which are making bi-lateral coordination at times difficult.

The second book review focuses on Jerry Langton's just released Gangland: The Rise of the Mexican Drug Cartels from El Paso to Vancouver (Wiley, 2012). The review is written by Samuel Logan, an investigative journalist, author of This is for the Mara Salvatrucha: Inside the MS-13, America's Most Violent Gang (Hyperion, 2009), and coauthor of the third book being reviewed in this special issue. While Langton's work is not viewed as being as comprehensive as some of the other books reviewed, and suffers from organizational problems, its value is seen as bringing in a Canadian perspective on the narco wars. Logan sees value in this third party-beyond Mexican and American-viewpoint on the conflict and how Canadians are very much troubled by the rampant corruption and lack of police professionalsim in Mexico.

Lisa Campbell, a senior U.S. intelligence officer who has conducted Los Zetas order-of-battle analysis, provides the third review. It pertains to George W. Grayson and Samuel Logans' much anticipated work The Executioner's Men: Los Zetas, Rogue Soldiers, Criminal Entrepreneurs, and the Shadow State They Created (Transaction Publishers, 2012). Campbell's review provides us insights into what currently represents the most comprehensive study on the origins, history, and activities of the Zetas cartel. Present activities of the cartel are also highlighted and discussed including their movement into Central America and on going war with their former employers, the Gulf cartel. Minor detractions of the work are the non-standard application of operational concepts and a somewhat chapter cocktail approach to facts, figures, and antecdotal evidence. Still, per Campbell, the work is highly readable and engaging and should be considered a first rate study.

The fourth review is that of the 2012 work by Ted Galen Carpenter entitled The Fire Next Door: Mexico's Drug Violence and the Threat to America (CATO Institute Press). The review is penned by Melissa Ziegler Rogers, an assistant professor at the Claremont Graduate University and specialist in Latin American politics. She provides a trechant analysis of Carpenter's work which is somewhat of an outlier for its promition of illicit drug legalization to help facilitate a reduction in violence and cartel profiting in Mexico. Both Calderón's and U.S. policies are analyzed and criticized in the work. While Carpenter is viewed as providing a strong legalization argument by Prof. Rogers, shortcomings in the work are seen to include a limited discussion of the economics of drug prohibition, lack of visuals to establish violence baselines, and an outright dismissal by the author of exploring policy options short of legalization (e.g. decriminalization and medicalization). 
Irina Chindea, a doctoral candidate at the Fletcher School of Law and Diplomacy, Tufts University, with a research focus on violent non-state actors, provides the fifth book review. This review is on Cartels at War: Mexico's Drug-Fueled Violence and the Threat to U.S. National Security (Potomac, 2012) by Paul Rexton Kan. Chindea's review is highly favorable towards the work which is viewed as being interdisciplinary, ambitious, and based on a deep understanding of the issues involved, albeit from an American perspective. The "high intensity crime" and "geo-criminality" perpectives expressed in the work, along with its acceptance of the mosaic nature of the conflict, are viewed as positive attributes. Detractions from the work are said to come from lack of full differentiation between perceptions of HIC (high intensity crime) and LIC (low intensity conflict) e.g. the possible political component of criminality, and a lack of gang and cartel definitions along with a few historical inaccuracies.

The sixth and final review is by Paul Rexton Kan an Associate Professor of National Security Studies with the U.S. Army War College and author of Drugs and Contemporary Warfare (Potomac, 2009) and Cartels at War which is the 5th work being reviewed in this special issue. He analyzes Sylvia Longmire's work Cartel: The Coming Invasion of Mexico's Drug Wars (Palgrave Macmillan, 2011). Dr. Kan provides both a complementary and critical review of the Longmire work which, while easy to read and providing rich detail, is said to suffer from a strategic misdagnosis concerning the 'coming invasion' and some issues with her recommended course of treatment. Further, Longmire's view of the terrorist and politicial attributes of the cartels - essentially their motivations - is at odds with Kan's anlysis which views them as criminal (eg. non-political) entities. Even with some of these perceived flaws, Dr. Kan considers the book to be valuable concerning the information provided regarding the origins and histories of the cartels and their various leaders.

This special issue also contains a Publication Monitor with a list of recent publications on organized crime - with an emphasis on works on the Mexican cartels.

The guest editor would like to thank the numerous contributors, and anonymous reviewers, to this special issue for their dedication, professionalism, and long hours spent in making it a success. He would also like to thank his wife Pamela Ligouri Bunker, a scholar in her own right, for her professional support in this endeavor and to Klaus von Lampe whose decision it was to allow me the opportunity to come on as an editor of a special issue of Trends in Organized Crime over the course of what turned out to be an almost 1 year endeavor.

\section{References}

Bunker R (1997) Epochal change: war over social and political organization. Parameters 27(2):15-25, http://www.carlisle.army.mil/usawc/parameters/Articles/97summer/bunker.htm

Bunker R (2011) The Mexican cartel debate: as viewed through five divergent fields of security studies. Small Wars J, http://smallwarsjournal.com/jrnl/art/the-mexican-cartel-debate

Felbab-Brown V (2010) Conceptualizing crime as competition in state-making and designing an effective response. Presentation at the "Conference on Illicit Trafficking Activities in the Western Hemisphere: Possible Strategies and Lessons Learned”, http://www.brookings.edu/speeches/2010/0521_illegal_ economies_felbabbrown.aspx 
Kan P (2011) What we're getting wrong about Mexico. Parameters 41(2):37-48

Kan P, Williams P (2010) Afterword: criminal violence in Mexico-a dissenting analysis. Small Wars Insurgencies 21(1):218-231

Mearsheimer J (2001) The tragedy of great power politics. W.W. Norton \& Company, New York

Metz S (1993) The future of insurgency, strategic studies institute. U.S. Army War College, Carlisle

Moore T (2003) The structure of war: early fourth epoch war research. In: Bunker R (ed) Non-state threats and future wars. Frank Cass, London, pp 159-170

Morgenthau H (1948) Politics among nations. Alfred A Knopf, New York

Sullivan J, Bunker R (2011) Rethinking insurgency: criminality, spirituality, and societal warfare in the Americas. Small Wars Insurgencies 22(5):742-763

Sullivan J, Elkus A (2010) Cartel vs cartel: Mexico's criminal insurgency. Small Wars J, http:// smallwarsjournal.com/jrnl/art/cartel-v-cartel-mexicos-criminal-insurgency

Tilly C (1985) War making and state making as organized crime. In: Evans P, Rueschemeyer D, Skocpol T (eds) Bringing the state back in. Cambridge University Press, Cambridge, pp 169-187

van Creveld M (1991) The transformation of war. The Free Press, New York

Waltz K (1979) Theory of international relations. Addison-Wesley, Reading 